Jurnal Interpretasi Hukum | ISSN: 2746-5047

Vol. 2, No. 3-Desember 2021, Hal. 578-583| Tersedia online di

https://www.ejournal.warmadewa.ac.id/index.php/juinhum

DOI: https://doi.org/10.22225/juinhum.2.3.4140.578-583

\title{
PENEGAKAN PERATURAN GUBERNUR BALI NOMOR 10 TAHUN 2021 DALAM TATANAN KEHIDUPAN ERA BARU
}

\author{
I Putu Aris Sedana Putra, Anak Agung Sagung Laksmi Dewi, Luh Putu Suryani \\ Fakultas Hukum, Universitas Warmadewa, Denpasar-Bali, Indonesia \\ laksmiidewi29@gmail.com, putusuryani099@gmail.com
}

\begin{abstract}
Abstrak
Munculnya pandemi Covid-19 telah memakan banyak korban jiwa dan berdampak pula pada segala aspek kenegaraan, maka Pemerintah Indonesia mengeluarkan Keppres No. 11 Tahun 2020 tentang Kedaruratan Kesehatan Masyarakat sebagai peringatan serius akan ancaman kesehatan. Ketidakjujuran penyampaian informasi pasien terduga terinfeksi covid-19 dikategorikan sebagai menghalangi penanggulangan wabah yang dapat mengancam nyawa orang di sekitarnya termasuk kepada tenaga kesehatan yang menanganinya. Tindakan menghalangi penanganan wabah dapat dipidana. Tujuan penelitian ini guna menganalisa pengaturan hukum protokol kesehatan dalam tatanan kehidupan baru serta sanksi bagi masyarakat yang tidak mengindahkan Pergub No. 10 Tahun 2021 di Bali. Metode penelitian ini menggunakan tipe penelitian hukum normatif dengan pendekatan konsep perundang-undangan. Teknik pengumpulan data dilakukan dengan cara meneliti bahan pustaka yang ada. Adapun sumber hukum yang digunakan terbagi dua yaitu sumber hukum primer dan sekunder yang kemudian diolah dan dianalisis secara sistematis. Simpulan dari hasil penelitian yang telah dilakukan adalah bahwa penerapan sanksi yang tegas kepada tindakan menghalangi penanggulangan wabah dipidana berdasarkan undang-undang nomor 4 tahun 1984 tentang Wabah Penyakit Menular pasal 14 ayat (1) dan (2). Pemerintah mengupayakan perlindungan kepada tenaga kesehatan sebagai garda depan penanganan ancaman covid-19 secara preventif maupun represif. Untuk itu diperlukan keterbukaan informasi kesehatan diri seseorang dengan mengungkapkan kondisi kesehatannya secara jujur kepada tenaga kesehatan untuk mendapatkan penanganan yang tepat.
\end{abstract}

Kata Kunci: Penegakan, Peraturan Gubernur, Tatanan Kehidupan Era Baru

\begin{abstract}
The emergence of the Covid-19 pandemic has claimed many lives and has an impact on all aspects of the state, the Indonesian Government issued Presidential Decree No. 11 of 2020 concerning Public Health Emergencies as a serious warning of health threats. Dishonesty in conveying information on patients suspected of being infected with COVID-19 is categorized as hindering the prevention of outbreaks that can threaten the lives of people around them, including the health workers who handle them. The act of obstructing the handling of the epidemic can be punished. The purposes of this study are to analyze the legal regulation of health protocols in the new life order and the sanctions for people who do not heed the Governor's Regulation No. 10 Year 2021 in Bali. This research method uses a normative legal research type with a statutory concept approach. Data collection techniques were carried out by examining existing library materials. The legal sources used are divided into two, namely primary and secondary legal sources which are then processed and analyzed systematically. The conclusion from the results of the research that has been carried out is that the application of strict sanctions to actions that hinder the prevention of epidemics is punishable by law number 4 of 1984 concerning Communicable Disease Outbreaks article 14 paragraphs (1) and (2). The government seeks to protect health workers as the vanguard of handling the threat of COVID-19 in a preventive and repressive manner. For this reason, it is necessary to disclose one's own health information by disclosing his health condition honestly to health workers to get the right treatment.
\end{abstract}

Keywords: Enforcement, Governor Regulation, New Era Life Order

\section{PENDAHULUAN}

Pandemi virus Corona yang melanda hampir seluruh dunia, berawal pertama kali di negara China tepatnya di kota Wuhan. Penyebaran virus corona terjadi sangat cepat melalui udara dan menyerang organ vital manusia yaitu saluran pernafasan. Virus Corona yang menjadi pandemi pada akhir tahun 2019 ini dinamakan Covid-19. Peningkatan jumlah korban meninggal dan perluasan wilayah terdampak Corona menyebabkan berbagai negara membuat kebijakan terhadap warga negaranya, tak terkecuali Indonesia dengan menetapkan pandemi Covid-19 sebagai kedaruratan kesehatan melalui 
penetapan Keppres No. 11 Tahun 2020 didasarkan pada undang-undang Kekarantinaan Kesehatan No. 6 tahun 2018. Besarnya ancaman kesehatan yang mengancam seluruh lapisan masyarakat membuat Pemerintah Indonesia dengan cepat dan tegas menyatakan pandemi ini sebagai kedaruratan kesehatan serta merespon kejadian luar biasa ini dengan pelaksanaan Pembatasan Sosial Berskala Besar (PSBB). Beberapa daerah juga mengeluarkan surat edaran mengenai pembatasan gerak sosial masyarakat serta mengkarantina wilayahnya dari segala aktivitas antar wilayah.

Berdasarkan Keppres No. 7 Tahun 2020, Pemerintah Indonesia membentuk Gugus Tugas penanganan Covid-19 melalui situs online www.covid19. go.id sebagai pusat informasi resmi covid-19 yang cepat, terpercaya, dan akurat. Segala berita terkini terkait penanggulangan covid-19 dapat diakses melalui situs online itu termasuk protokol kesehatan yang wajib dipatuhi masyarakat selama pandemi. Protokol kesehatan yang wajib dipatuhi oleh seluruh masyarakat diantaranya, rajin mencuci tangan dengan sabun di air mengalir atau selalu membawa cairan pencuci tangan berbasis alkohol (Megaartha, 2021). Kemudian wajib menggunakan masker saat keluar rumah, serta menjaga jarak minimal 1 (satu) meter dengan orang lain yang biasa disebut physical distancing. Melalui protokol kesehatan, masyarakat diajak untuk berperilaku hidup bersih dalam kesehariannya guna menekan penyebaran covid-19.

Dalam penanganan covid-19, komunikasi menjadi hal yang penting guna memberikan informasi secara terbuka kepada masyarakat dalam hal preventif maupun represif penanganan penyebaran virus corona. Bentuk komunikasi Gubernur Bali terkait disiplin protokol kesehatan adalah melalui sosialisasi kepada masyarakat dengan memberikan pengingat tentang protokol kesehatan di setiap sektor usaha masyarakat serta menghimbau para pemegang kepentingan untuk tetap melaksanakan imbauan tersebut. Dengan segala bentuk usaha dari Kepala Daerah diharapkan masyarakat mulai terbiasa untuk beradaptasi dengan kebiasaan pola hidup bersih dan sehat. Kepala Daerah Bali, dalam hal ini adalah Gubernur, bekerjasama dengan seluruh instansi terkait guna mengawasi jalannya penegakan hukum disiplin protokol kesehatan melalui operasi yustisi yang digelar di wilayahnya. Instansi yang terkait meliputi, instansi rumah sakit untuk mencatat data pasien terinfeksi virus corona. Dinas Perhubungan melalui Satuan Polisi Pamong Praja (Satpol PP) sebagai pengawas pelaksanaan protokol kesehatan bekerjasama dengan TNI-Polri, dan Desa Adat dengan Satuan polisi adatnya yang disebut sebagai pecalang, beserta instansi terkait lainnya. Pada dasarnya penetapan kebijakan tatanan normal baru yang diterapkan di daerah-daerah yang telah dinyatakan layak oleh pemerintah akan berimplikasi kepada berbagai aspek kehidupan khususnya pada aspek ekonomi dan sosial (Herdiana \& Nurul, 2020).

Kekosongan hukum yang terjadi hingga diterbitkannya Perppu mengenai stabilitas sistem keuangan negara adalah dalam hal pengaturan pembiayaan dan peningkatan belanja negara. Pengaturan pembiayaan dan peningkatan belanja negara diperlukan sebagai upaya pemerintah dalam penyelamatan perekonomian nasional. Atas permasalahan kesehatan dan perekonomian nasional yang kian memburuk secara cepat, maka pemerintah melakukan tindakan antisipasi dalam rangka menjaga stabilitas sektor keuangan melalui penerbitan Perpu (Atmadja, I Dewa Gede Budiartha, 2018). Pembatasan Sosial Berskala Besar (PSBB) memberlakukan segala aktivitas masyarakat dilakukan di rumah melalui internet, termasuk bekerja dan bersekolah dari rumah. Namun pembatasan tersebut tidak berlaku bagi para tenaga kesehatan karena pelayanan kepada pasien rawat inap hanya dapat dilakukan secara langsung. Tenaga kesehatan merupakan garda depan penanganan pasien covid-19 sehingga mereka menjadi kelompok rentan untuk tertular. Untuk itulah perlindungan terhadap tenaga kesehatan diperlukan guna tetap dapat memberikan pelayanan kepada pasien di tengah situasi darurat saat ini.

Dampak kesehatan serius dari penularan Covid 19 dapat menyebabkan kematian membuat masyarakat merasa khawatir tertular virus Corona. Kekhawatiran tersebut terlihat dari pengucilan kepada penderita covid 19 beserta keluarganya. Tidak semua penderita covid 19 memperlihatkan gejala penyakit ini secara nyata, sehingga bagi orang yang memiliki riwayat perjalanan ke zona penularan corona maka ia wajib diperiksa kesehatannya guna menekan penularan penyakit. Dampak psikologis berupa pengucilan kepada penderita covid 19 beserta keluarganya yang terjadi di tengah masyarakat membuat sebagian orang memilih untuk tidak jujur atas kondisi kesehatan mereka. Seluruh dimensi kehidupan bermasyarakat dan bernegara di Indonesia harus berdasarkan aturan hukum guna mewujudkan tujuan hukum yang adil dengan memperhatikan hak dan kewajiban setiap warga negara. Selain mengatur hak dan kewajiban warga negara, hukum juga berfungsi sebagai 
instrumen perlindungan bagi subjek hukum. Pelanggaran terhadap aturan hukum dapat menimbulkan reaksi berupa tindakan disorder atau ketidakteraturan hukum dalam masyarakat. Setiap pelanggaran atas aturan hukum mengakibatkan dikenakannya sanksi sebagai alat pemaksa diberlakukannya peraturan tersebut. Sanksi menurut ketentuan undang-undang terbagi atas sanksi perdata, sanksi administratif, dan sanksi pidana. Sanksi pidana bersifat lebih tajam daripada sanksi lainnya karena adanya penderitaan yang sengaja ditimpakan kepada pelanggar yang melawan hukum.

Penegakan hukum wajib memperhatikan unsur kepastian hukum, kemanfaatan, dan keadilan secara seimbang. Undang-undang dibuat dengan jelas dan logis agar tidak menimbulkan multitafsir yang mengakibatkan konflik norma. Selain itu hukum juga memberikan kepada setiap orang atas apa yang menjadi haknya berdampingan dengan kewajibannya. Keputusan sanksi ditetapkan agar bermanfaat bagi rakyat banyak. Hak pasien adalah memperoleh pelayanan yang baik dari tenaga kesehatan sehubungan dengan penyakit yang dideritanya, sejalan dengan itu kewajiban memberikan informasi mengenai kondisi kesehatan dan riwayat perjalanannya selama wabah berlangsung harus diberikan sejujurnya agar penanganan pengobatan dapat dicapai maksimal. Ketidakjujuran berkaitan keterangan yang disampaikan saat kejadian luar biasa padahal orang tersebut patut diduga terinfeksi covid-19 dapat dikategorikan sebagai tindakan menghalangi penanganan wabah sehingga berdasarkan undang-undang dapat dipidana.

Penelitian sebelumnya dari Mahadewi (2021) menunjukan bahwa Kebijakan Pelaksanaan PKKM Darurat berdasarkan Surat Edaran Gubernur perlu diadakan evaluasi ulang, belum adanya muatan hukum dalam aturan penangannya, belum adanya sosialiasai akan aturan hukum penerapannya masih rancu di masayarakat, belum menyertakan Undang-undang Karantina Kesahatan, Wabah penyakakit, perdagangan dan ITE agar aturan lebih jelas dan efektif. Sedangkan menurut Pramesti (2020) pemerintah desa Batubulan telah bekerja sama dengan desa adat dan kepala dusun untuk mensosialisasikan kebijakan ini baik dengan media elektronik maupun peringatan yang berupa poster/banner dan dalam hal ini menunjukan bahwa masyarakat desa Batubulan telah turut aktif dan partisipatif dalam mencegah penyebaran virus corona dengan mematuhi himbauan dan peraturan yang disampaikan pemerintah. Lebih lanjut, Putra \& Wijaya (2021) menjelaskan bahwa Tatanan Kehidupan Era Baru yang diimplementasikan di Kota Amlapura Kabupaten Karangasem dilihat dari segi budaya hukum masih belum baik dan menjadi kendala. Kendala yang dijumpai yaitu belum dimilikinya kesadaran hukum yang baik, tercermin dari banyaknya jumlah angka pelanggaran protokol kesehatan, dan masih banyaknya masyarakat yang belum mengerti mengenai aturan ini. Maka berdasarkan penelitian sebelumnya, maka pengaturan hukum protokol kesehatan dalam tatanan kehidupan baru serta sanksi bagi masyarakat yang tidak mengindahkan Pergub No. 10 Tahun 2021 di Bali perlu ditinjau secara mendalam guna kemaslahatan manusia.

\section{METODE PENELITIAN}

Penelitian ini dilakukan dengan mencari data melalui buku ilmu hukum dan menghubungkan dengan permasalahan yang diangkat kemudian mengkaitkan dengan perundang-undangan yang berlaku saat ini. Dari segi hukum penelitian ini termasuk penelitian normatif dengan pendekatan perundangundangan (Amiruddin \& Asikin, 2010). Teknik pengumpulan data yang digunakan dalam penelitian ini adalah teknik studi kepustakaan.Penulis mengkaitkan dengan peraturan yang berlaku dan tidak menyimpang dari undang-ndang dasar. Pendekatan penelitian dengan cara mengkaji, mencari dan memilah data dari berbagai buku hukum dan berpatokan pada undang-undang sebagai dasar penulisan skripsi. Penelitian ini bertujuan mencari informasi yang akurat dengan mempelajari gejala masyarakat untuk mendapatkan data yang sebenar-benarnya. Dengan demikian data dapat digabungkan dengan berbagai referensi buku hukum yang terkait dan menghasilkan penelitian yang tidak melenceng dari hukum positif (Saebani, 2008). Adapun bahan hukum terdiri dari bahan hukum primer yang didapat dengan menganalisis peraturan perundang-undangan, risalah resmi, dan beberapa keputusan-keputusan yang menyangkut dengan judul tulisan ini. Bahan hukum sekunder didapat dari menganalisis buku-buku, jurnal-jurnal dan hasil-hasil penelitian terdahulu yang memiliki keterkaitan dengan judul penulisan ini yang kemudian analisis dengan sistematis. 


\section{HASIL DAN PEMBAHASAN}

\section{Pengaturan Hukum Protokol Kesehatan Dalam Tatanan Kehidupan Baru}

Pada hakekatnya, hukum bersifat mengatur, memaksakan segala aturannya dan memberikan sanksi bagi pelanggar hukum. Melanggar aturan hukum dikatakan sebagai tindakan melawan hukum karena pelanggaran undang-undang yang merugikan masyarakat. Untuk itu penegakan hukum harus dilakukan dengan pemberian sanksi demi terwujudnya ketertiban hukum dalam upaya memberikan perlindungan kepada masyarakat. Penegakan hukum merupakan kegiatan menyerasikan hubungan nilai-nilai dalam aturan hukum kemudian merealisasikannya dalam sikap dan tindakan hukum harus memperhatikan kepastian hukum, kemanfaatan, dan keadilan. ketiga unsur tersebut harus diusahakan untuk dilaksanakan secara proporsional dan seimbang. Bila keseimbangan itu tidak mungkin dilaksanakan maka keadilan harus diprioritaskan, kemudian kemanfaatan hingga akhirnya pada kepastian hukum (Saleh, 2012).

Keadilan dalam kaitannya dengan hubungan antar manusia adalah mengenai hak dan kewajiban yang dilaksanakan secara proporsional. Asas keadilan dan kepastian hukum juga disertai dengan asas kemanfaatan guna menjaga kestabilan di dalam masyarakat. Sebagai bentuk kepastian hukumnya, maka penerapan sanksi yang diberlakukan bagi pelanggar aturan hukum merupakan tindakan nyatanya. Bentuk upaya pemerintah dalam memberikan perlindungan kepada masyarakat dapat berupa meningkatkan derajat kesehatan masyarakat melalui pelayanan kesehatan sesuai nilainilai hak asasi manusia. Pemenuhan hak kesehatan kepada masyarakat juga memerlukan peran dari masyarakat itu sendiri, seperti misalnya mengikuti anjuran pemerintah dalam upaya menekan laju penyebaran penyakit. Membantu tenaga kesehatan dengan memberikan keterangan yang benar mengenai riwayat penyakitnya agar pengobatan dapat diberikan dengan tepat.

Dalam pelayanan kesehatan tidak terlepas dari hubungan antara dokter dengan pasien dilihat dari adanya transaksi terapeutik yang melahirkan hak dan kewajiban bagi kedua belah pihak. Pelayanan pada dasarnya dikatakan sebagai usaha untuk membantu menyiapkan segala hal yang dibutuhkan orang lain hingga mencapai keinginan yang diharapkan oleh konsumen. Dalam transaksi terapeutik, konsumen adalah orang sakit (pasien) yang meminta pengobatan kepada dokter. Para pihak dalam transaksi terapeutik memiliki posisi sederajat sehingga menempatkan keduanya pada kedudukan tanggung gugat yang sama. Tindakan terapeutik yang dilakukan tenaga kesehatan selalu berdasarkan pedoman pelaksanaan tugas sesuai fungsi juga sebagai alat penilaian kinerja bagi instansi pemerintah maupun non pemerintah. Transaksi terapeutik menciptakan perjanjian antara tenaga kesehatan dengan pasien yang diatur di dalam hukum perjanjian utamanya pasal 1320 BW terkait syarat sah perjanjian. Syarat kesepakatan dalam transaksi terapeutik dapat dilihat dari ditandatanganinya perjanjian antara pasien atau penanggungjawab pasien dalam menerima pengobatan atau pasien tersebut telah setuju menerima pelayanan kesehatan dari dokter. Syarat kecakapan juga terlihat dari usia pasien atau usia penanggungjawab pasien yang menandatangani perjanjian, yaitu telah berusia genap 21 tahun atau lebih. Kemudian syarat hal tertentu merupakan bahwa pengobatan yang diberikan adalah telah sesuai dengan standar pelayanan kesehatan dan tidak bertentangan dengan ketentuan hukum yang berlaku. Sebagai syarat keempat yaitu sebab yang halal, bahwa pengobatan yang diberikan oleh dokter atau rumah sakit tidak bertentangan dengan undangundang kesehatan atau juga tidak melanggar kode etik kedokteran. Perjanjian tersebut menimbulkan akibat hukum dimana perjanjian yang dibuat itu berlaku sebagai undang-undang bagi para pihak. Perjanjian tidak dapat ditarik kembali tanpa kesepakatan kedua belah pihak kecuali ada alasan lain yang diperbolehkan oleh undang-undang. Asas itikad baik selalu dijunjung dalam pembuatan perjanjian. Penerapan asas itikad baik dalam perjanjian terapeutik dapat dilihat dari hak dan kewajiban yang dilaksanakan secara timbal balik. Seperti misalnya, kejujuran pasien dalam memberikan informasi tentang gejala penyakitnya serta pemberian pelayanan medik dari tenaga medis yang didasarkan pada keahlian dan keterampilan mereka.

Dalam penanganan covid-19, komunikasi menjadi hal yang penting guna memberikan informasi secara terbuka kepada masyarakat dalam hal preventif maupun represif penanganan penyebaran virus corona. Bentuk komunikasi Gubernur Bali terkait disiplin protokol kesehatan adalah melalui sosialisasi kepada masyarakat dengan memberikan pengingat tentang protokol kesehatan di setiap sektor usaha masyarakat serta menghimbau para pemegang kepentingan untuk tetap melaksanakan imbauan tersebut. Dengan segala bentuk usaha dari Kepala Daerah diharapkan masyarakat mulai terbiasa untuk beradaptasi dengan kebiasaan pola hidup bersih dan sehat. Kepala 
Daerah Bali, dalam hal ini adalah Gubernur, bekerjasama dengan seluruh instansi terkait guna mengawasi jalannya penegakan hukum disiplin protokol kesehatan instansi rumah sakit untuk mencatat data pasien terinfeksi virus corona. Dinas Perhubungan melalui Satuan Polisi Pamong Praja (Satpol PP) sebagai pengawas pelaksanaan protokol kesehatan bekerjasama dengan TNI-Polri, dan Desa Adat dengan Satuan polisi adatnya yang disebut sebagai pecalang, beserta instansi terkait lainnya melalui operasi yustisi yang digelar di wilayahnya. Instansi yang terkait.

\section{Sanksi Bagi Masyarakat yang Tidak Mengindahkan Pergub No. 10 Tahun 2021 di Bali}

Menindaklanjuti tanggung jawab negara kepada warga negaranya pada situasi pandemi Covid-19, maka Pemerintah melakukan tindakan perlindungan hukum preventif dengan mengeluarkan kebijakan terkait keselamatan tenaga kesehatan selama bertugas mendapat perhatian ekstra melalui pemberian Alat Pelindung Diri (APD), pemberian vitamin, makanan dan air mineral. Penerapan physical distancing sebagai salah satu cara meminimalisir penularan secara langsung di samping penyediaan hand sanitizer di lingkungan rumah sakit serta keharusan menggunakan masker bagi pasien yang datang ke rumah sakit untuk mengurangi tingkat penularan lewat udara saat pasien batuk atau bersin. Bila telah terjadi pelanggaran terhadap upaya perlindungan hukum preventif maka secara tegas berlaku perlindungan akhir berupa sanksi sebagai bentuk perlindungan hukum secara represif. Perlindungan hukum ini diberikan untuk menyelesaikan sengketa suatu pelanggaran yang telah terjadi dengan tetap mengindahkan perlindungan terhadap hak asasi manusia.

Sanksi memiliki tiga komponen dengan perannya masing-masing, yaitu sebagai alat pemulih keadaan, sebagai pemenuh keadaan, dan hukuman. Terhadap perbuatan seseorang yang merugikan orang lain dan melanggar ketentuan hukum digolongkan kedalam perbuatan melawan hukum. Imbauan pemerintah tentang kewajiban melaksanakan protokol kesehatan bagi masyarakat kerap kali dilanggar sehingga pemerintah daerah menerapkan sanksi berupa sanksi denda dan sanksi sosial, seperti membersihkan fasilitas umum atau membayar sejumlah uang karena tidak menggunakan masker saat berinteraksi dengan orang lain (Asshidiqie, 2007). Peraturan-peraturan gubernur tersebut menyertakan sanksi yang ditujukan kepada perorangan, pelaku usaha, pengelola usaha, penyelenggara, penanggungjawab tempat dan fasilitas umum yang terbukti melanggar protokol kesehatan maupun melanggar PSBB. Jenis sanksi bagi pelanggar himbauan pemerintah ataupun protokol kesehatan, seperti sanksi sosial berupa publikasi di media massa bagi perusahaan yang bandel tidak menerapkan protokol kesehatan di tempat usahanya. Kemudian adanya sanksi administratif berupa teguran maupun pemberhentian usaha sementara, serta sanksi denda. Bila pelanggar tidak kooperatif, maka diancam dengan sanksi pidana berdasarkan ketentuan pasal $93 \mathrm{UU}$ Nomor 6 tahun 2018 tentang Kekarantinaan Kesehatan.

\section{SIMPULAN DAN SARAN}

\section{Simpulan}

Penegakan hukum identik dengan pemberian sanksi bagi para pelanggarnya serta merupakan syarat terwujudnya perlindungan hukum untuk setiap orang dengan memperhatikan unsur kepastian hukum, kemanfaatan, dan keadilan. Keberlakuan sanksi terhadap perbuatan melawan hukum yang merugikan masyarakat penting diterapkan guna memastikan peraturan tidak dilanggar. Peraturan yang dikeluarkan pemerintah terkait covid-19 salah satunya adalah Keppres No. 11/2020 tentang Kedaruratan Kesehatan Masyarakat sebagai bentuk peringatan kepada masyarakat akan bahaya virus Corona yang tengah melanda hampir seluruh dunia. Diperlukan kerjasama yang baik dari berbagai pihak dalam upaya penanggulangan wabah ini diantaranya dengan berlaku jujur dalam memberikan keterangan mengenai kesehatannya kepada tenaga kesehatan agar pengobatan dapat dilakukan secara cepat dan tepat. Kejujuran akan menyelamatkan banyak nyawa termasuk nyawa tenaga kesehatan yang sedang bertugas menangani pasien terinfeksi covid-19. Ketidakjujuran dalam memberikan informasi kondisi kesehatan tergolong tindakan menghalangi penanggulangan wabah. Demi mengurangi tingginya indeks kematian tenaga kesehatan selama pandemi virus corona, pemerintah berupaya memberikan perlindungan kepada tenaga kesehatan yang bertujuan menciptakan rasa aman melalui perlindungan preventif maupun perlindungan represif. Perlindungan hukum preventif ditujukan kepada tenaga kesehatan melalui pemenuhan kebutuhan selama bertugas seperti pemberian jaminan berupa penyediaan Alat Pelindung Diri (APD), pemberian vitamin dan makanan kepada tenaga kesehatan merupakan upaya pemerintah melindungi garda depan penanganan covid-19. Ketika 
seluruh upaya preventif telah dilakukan namun terjadi pelanggaran ataupun sengketa, maka upaya perlindungan represif dilakukan melalui penerapan sanksi hukum bagi pelanggar aturan hukum.

\section{Saran}

Ketentuan pidana tidak menyebutkan secara spesifik kondisi jika pasien berbohong, namun penafsiran mengenai orang yang tidak jujur bisa dikategorikan menghalang-halangi penanggulangan wabah, perlu mendapatkan penjelasan secara spesifik agar tidak menimbulkan pro dan kontra ataupun multitafsir sehingga sanksi yang diberikan dapat memenuhi unsur kepastian hukum, kemanfaatan, dan keadilan. Diperlukan kesadaran dan kerjasama yang baik antara masyarakat dengan pemerintah dalam penanggulangan wabah penyakit menular, salah satunya adalah dengan memberikan informasi yang jujur mengenai kondisi kesehatannya kepada tenaga kesehatan sebagai bentuk kewajiban yang harus dilaksanakan.

\section{DAFTAR PUSTAKA}

Amiruddin, \& Asikin, Z. (2010). Pengantar Metode Penelitan Hukum. Rajawali Pers, Jakarta.

Asshidiqie, J. (2007). Konstitusi dan Ketatanegaraan Indonesia Kontemporer. The Biography Institut, Jakarta.

Atmadja, I Dewa Gede Budiartha, I. N. P. (2018). Teori-teori Hukum. Setara Press, Malang.

Herdiana, D., \& Nurul, S. (2020). Implikasi Tatanan Normal Baru Terhadap Kehidupan Sosial Kemasyarakatan. Jurnal Ilmiah Dinamika Sosial, 4(2), 300-328.

Mahadewi, K. J. (2021). Kebijakan Pelaksanaan PPKM Darurat untuk Penanganan Covid-19 Dalam Tatanan Kehidupan Era Baru di Provinsi Bali. Jurnal Kertha Semaya, 9(10), 1879-1895.

Megaartha, S. A. M. R. (2021). Optimalisasi dan Adaptasi Kultur Perekonomian Baru Di Era Pandemi Covid-19 Guna Menggerakan Roda Perekonomian Khususnya Pada Usaha Penginapan di Bali. AcityaArdana, 1(1), 18-29.

Pramesti, D. A. A. I. (2020). Implementasi Peraturan Gubernur Bali No.46 Tahun 2020 Di Desa Batubulan. Kertha Wicara, 10(1), 71-82.

Putra, I. G. A. M., \& Wijaya, M. H. (2021). Pelaksanaan Peraturan Gubernur Bali Nomor 46 Tahun 2020 Tentang Penerapan Disiplin dan Penegakan Hukum Protokol Kesehatan Sebagai Upaya Pencegahan dan Pengendalian Corona Virus Disease 2019 Dalam Tatanan Kehidupan Era Baru di Kota Amlapura Kabupaten Karan. Jurnal Mahasiswa Hukum Saraswati, 1(1), 49-68.

Saebani, B. A. (2008). Metode Penelitian. Pustaka Setia. Bandung.

Saleh, B. W. (2012). Kebijakan Publik Teori, Proses, dan Studi Kasus. CAPS, Yogyakarta. 